УДК 338.432: 631.115: 338.433

(C) 2012

Аранчій В. І., кандидат економічних наук, професор,

Зоря О. П., кандидат економічних наук,

Пісоцький А. А., здобувач *

Полтавська державна аграрна академія

\title{
НЕОБХІДНІСТЬ І ЗНАЧЕННЯ ЕКОНОМІЧНОГО РЕГУЛЮВАННЯ АГРАРНОГО ВИРОБНИЦТВА
}

\author{
Рецензент - доктор економічних наук, професор П. М. Макаренко
}

Узагальнено теоретичні підходи щзодо необхідності та значення економічного регулювання аграрного виробництва в умовах ринкового розвитку. Визначено роль держави в регулюванні аграрного виробництва. Встановлено, шзо економічне регулювання аграрного виробництва повинно здійснюватися в межах аграрної політики держави шляхом застосування цінового, кредитно-інвестиційного та податкового механізмів із метою формування ефективного виробництва сільськогосподарської продукиї.

Ключові слова: держава, економічне регулювання, розвиток, аграрне виробництво, підтримка.

Постановка проблеми. В умовах розвитку та ринкової трансформації аграрного сектора України принципового значення набувають питання удосконалення форми і методів економічного регулювання виробництва, спрямованих на забезпечення продовольчої безпеки країни, створення умов для постійного нарощування виробництва аграрної продукції та забезпечення всебічної підтримки товаровиробників.

Ефективність ринкової системи господарювання в аграрній сфері залежить від активної регулюючої функції держави й продукування нею економічних умов для розвитку виробництва. 3 огляду на це, ефективність функціонування агроекономічної системи залежить від раціонального вирішення питань розвитку аграрної економіки на мікрорівні.

Аналіз основних досліджень і публікацій, у яких започатковано розв'язання проблеми. Не дивлячись на важливість збалансованого поєднання державного і ринкового регулювання для економічного зростання аграрного виробництва, воно як у теоретичному, так і практичному аспекті допоки що залишається малодослідженим. Це обумовлюється, на нашу думку, багатогранним характером можливої державної підтримки розвитку аграрного виробництва, особливостей здійснення економічного регулювання в країні та повільним реформуванням соціально-економічних відносин на селі.

Проблеми економічного регулювання розвитку аграрного виробництва розкриті в працях таких відомих вчених: В. Амбросова [1], В. Андрійчука [2], Т. Лозинської [3], П. Макаренка [4], М. Маліка [5], П. Саблука [6], О. Шпикуляка [7] та інших.

Проте в умовах подальшого реформування аграрного виробництва механізми регулювання економічних взаємовідносин потребують поглибленого дослідження, зокрема щодо необхідності та значення економічного регулювання, визначення його ефективності на макроекономічному й господарському рівнях, а також розробки напрямів його удосконалення на майбутнє.

Метою роботи $є$ визначення сутності та значення економічного регулювання розвитку аграрного виробництва в сучасних умовах.

Результати дослідження. Ринковий механізм i державне регулювання розвитку аграрної сфери $\epsilon$ взаємодоповнюючими елементами сучасної економіки в Україні. Держава повинна виконувати лише ті функції, яких не може забезпечити ринок, тому за нею завжди зберігатимуться такі основні завдання, як створення правової бази, захист конкуренції та прав власності, розподіл і перерозподіл доходів. Змінюються лише пріоритети регулювання, поскільки кожний конкретний період часу потребує різних цілей, які повинні співпадати з сучасними підходами та принципами державного регулювання економіки. Державне втручання в аграрне виробництво, з нашого погляду, має бути раціональним - надмірність або недостатність заважають розвитку, породжуючи негативні тенденції й наслідки, які ми можемо спостерігати в наш час.

* Керівник-кандидат економічних наук, професор В. І. Аранчій 


\section{EKOHOMIKA}

В аграрній сфері, порівняно із іншими галузями національної економіки, процес регулювання виробництва значно ускладнюється необхідністю поєднання в аграрних підприємствах декількох товарних галузей, які суттєво відрізняються за організацією та процесом виробництва, розосередженістю виробництва на відносно великій території, що ускладнює процес прийняття оперативних управлінських рішень, значною залежністю ефективності виробництва від природно-кліматичних умов та сезонністю виробництва.

Саме ці причини й негативні наслідки трансформації аграрних відносин, а також необхідність захисту національних інтересів на світовому ринку зумовлюють необхідність втручання держави стосовно розвитку й підвищення ефективності аграрного виробництва.

Стимулювання розвитку аграрного виробництва повинно здійснюватися методами державної підтримки, зокрема, цінового регулювання, заходами щодо зниження податкового тиску, створенням сприятливих умов для кредитування виробництва, фінансово-інвестиційного забезпечення, політики державного протекціонізму, реструктуризації боргів у сільському господарстві та залучення інозем- них інвестицій.

Ситуація, що склалася сьогодні в аграрному секторі, свідчить про необхідність формування дієвого механізму економічного регулювання. Оптимальне поєднання державного регулювання економіки з ринковими регуляторами повинно забезпечити вихід аграрного сектора $з$ кризи, дати можливість досягти високої ефективності аграрного виробництва та конкурентоспроможності вітчизняної продукції на міжнародному ринку.

Перспективи розвитку вітчизняного аграрного виробництва і ринку залежать від ефективності впливу на них відповідних механізмів. Ці механізми все ще формуються, залишаючись здебільшого недосконалими, такими, що не відповідають інтересам учасників ринкового обміну й безпосередньо залежать від існуючих умов іх функціонування. Механізми регулювання аграрного виробництва включають у себе структурні складові, які доцільно розділити на правові й економічні (див. рис.).

У ринкових умовах в частині удосконалення механізму регулювання аграрного виробництва пріоритетного значення набуває протекціонізм щодо розвитку відповідних галузей та виробництв через інструменти правового й економічного механізмів. Даний напрям дає змогу еволюційним шляхом забезпечити в аграрних підприємствах можливості

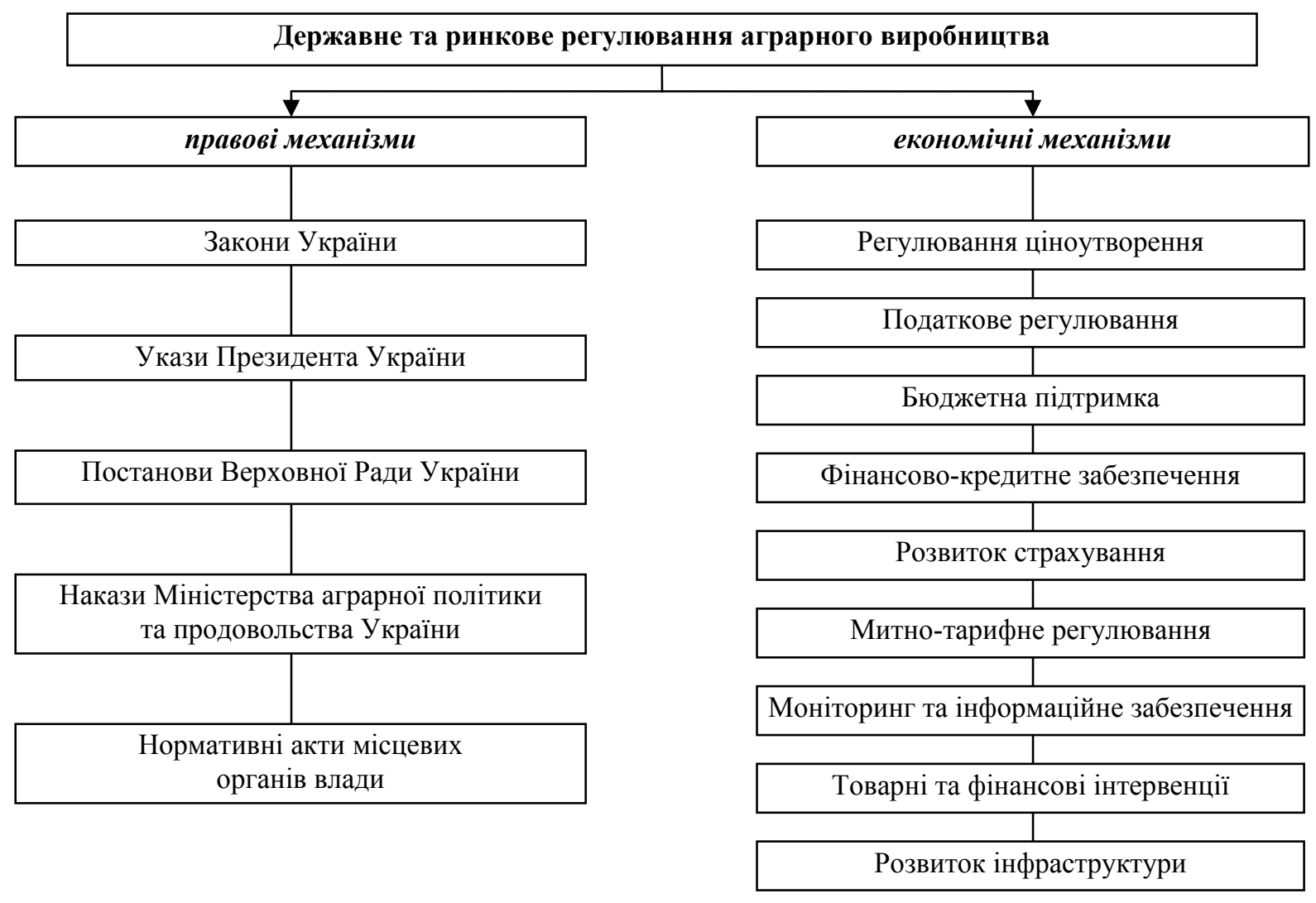

Рис. Складові механізму регулювання аграрного виробництва 
виробляти конкурентоспроможну продукцію. Для досягнення цієї мети слід удосконалити існуючі й сформувати нові інструменти реалізації протекціоністських заходів, що дасть можливість створити передумови для реалізації функцій аграрного протекціонізму в частині забезпечення високого рівня доходності аграрних підприємств, необхідного для розвитку в галузі інвестиційного клімату та попиту на інновації з боку товаровиробників.

\section{Висновки:}

1. Економічне регулювання аграрного виробництва повинно здійснюватися в межах аграрної політики держави шляхом застосування цінового, кредитно-інвестиційного та податкового механізмів із метою формування ефективного виробництва сільськогосподарської продукції.

2. Державна підтримка і стимулювання в аграрному секторі ефективного ринкового середовища має носити комплексний характер i поєднувати такі важелі економічного регулювання: цінову політику, податкові пільги, гарантії щодо залучення іноземних інвестицій, фінансово-кредитне забезпечення, сприяння роз-

\section{БІБЛІОГРАФІЯ}

1. Амбросов В. Я. Наукові положення удосконалення економічного і господарського механізмів розвитку сільського господарства / В. Я. Амбросов, Т. Г. Маренич // Економіка АПК. - 2005. - № 10. - С. 14-19.

2. Андрійчук В. Г. Сучасна аграрна політика: проблемні аспекти / В. Г. Андрійчук, М. В. Зубець, В. В. Юрчишин. - К.: Аграрна наука, 2005. - $140 \mathrm{c}$.

3. Лозинська T. М. Національний продовольчий ринок в умовах глобалізації: [монограф.] / Т. М. Лозинська. - Х.: Вид-во ХарРІ НАДУ «Магістр», 2007. - 272 с. витку страхування, митно-тарифне регулювання, бюджетну підтримку.

3. Економічне регулювання розвитку аграрного виробництва повинно поєднувати в собі два напрями:

- підвищення економічної ефективності аграрного виробництва за рахунок розвитку ринкової інфраструктури, інформаційне й науковометодичне забезпечення суб'єктів господарювання, забезпечення індикативного регулювання, забезпечення соціального захисту населення та розвитку сільських територій;

- цільове регулювання складових аграрного сектора регіону здійснювати 3 допомогою сприяння розвитку інтеграційних процесів за ланцюгом "виробництво - переробка - реалізація"; підтримки спеціалізації й концентрації виробництва і переробки аграрної продукції; впровадження нових стандартів якості як продукції, так і роботи аграрних підприємств, а також контролю за дотриманням цих стандартів; здійснення політики інтервенції стосовно продуктів тривалого зберігання з метою згладження сезонних коливань на ринку аграрної продукції.

4. Макаренко П. М. Моделі аграрної економіки / П. М. Макаренко. - К.: ННЦ IAЕ, 2005. - 682 с.

5. Малік М. Й. Державне регулювання аграрного сектора економіки в дослідженнях вітчизняних вчених / М. Й. Малік, Ю. О. Лупенко // Економіка АПК. - 2009. - № 10. - С. 153-158.

6. Саблук П. Т. Економічний механізм АПК у ринковій системі господарювання / П. Т. Саблук // Економіка АПК. - 2007. - № 2. - С. 3-10.

7. Шиикуляк $О . Г$. Інституції у розвитку та регулюванні аграрного ринку : монографія / Шпикуляк О. Г. - К. : ННЦ IAE, 2010. - 74 с. 